\title{
LIVING AND LEARNING IN THE GLOBAL VILLAGE
}

\author{
Gene Burdenuk \\ Associate Professor \\ Faculty of Education \\ The University of Western Ontario \\ 1137 Western Road \\ London, Ontario, Canada \\ N6G 1G7 \\ E-mail: burdenuk@edu.uwo.ca
}

\begin{abstract}
This paper begins with a discussion of some of the promises and pitfalls confronting education in the Information Age. After exploring the business motivation that drives the education agenda and examining what some futurists are calling the end of the job, we identify four principles or themes that could help transform education as we approach the millennium. We argue that critical literacy, connectivity, creating a civil society and critical multiculturalism can foster an educational system that could resolve economic, cultural and social inequities. The information highway offers unprecedented opportunities for educators to create collaborative learning environments that will stimulate critical thinking skills and academic excellence among all students.
\end{abstract}

\section{INTRODUCTION}

There is an old rabbinic tale, which goes: And the Lord said to the Rabbi "Come, I will show you hell." They entered a room where a group of people sat around a huge pot of stew. Everyone was famished and desperate. Each held a spoon that reached the pot but had a handle so long it could not be used to reach their mouths. The suffering was terrible.

"Come, now I will show you heaven," the Lord said after a while, they entered another room, identical to the first(the pot of stew, the group of people, the same long spoons. But there everyone was happy and nourished. "I don't understand," said the Rabbi. "Why are they happy here when they were miserable in the other rabbi and everything was the same?" The Lord smiled. "Ah, but don't you see?" He said. "Here they have learned to feed each other." Aram Das

As we are about to embark upon the new millennium Aram Das' tale assumes even more relevance as it illustrates the dilemma that we face in living and learning in the global village. The global village, that hypothetical construct first popularized by Marshall McLuhan more than thirty years ago, has now become a reality. The world is shrinking, traditional political economic and social boundaries are being redefined daily. Global networks such as The General Agreement on Trade and Tariffs (GATT), the Maastricht Accord, the North American Free Trade Agreement (NAFTA) and, of course, the Internet have changed the way we work, teach and live. "The shift from an economy based on material energy and labour to one based on information and communication further reduces the importance of the nation state as a critical player in guaranteeing safety and security for its citizens." (Rifkin, 1995, p. 236) Some see the development of the global village as a way of extending business control over our lives and continuing to exacerbate the differences between the haves and the have-nots, the north and the south, and the first and third worlds (Barlow \& Robertson, 1994). While others see an opportunity for restructuring schools and society to create a world of equality and social justice that could lead to moral spiritual and educational growth for all (Cummins \& Sayers, 1995). Governments, faced with increasing debt loads and pressure from tax payers, have 
singled out education, social services and health care as areas of major financial cutbacks. In doing so, they have complained that our educational systems have failed in providing a skilled labor force for the marketplace. Pressure is upon us to return to teaching the basics (Wadsworth, 1997). Others see that the new information technology is all that is needed to cure the ills of today's schools. "Wire every school" is the cry and all the problems of education will disappear (Rhodes, 1996).

Computer-based technologies can administer individualized lesson sequences that branch and remediate according to students unique needs, quickly and automatically track progress, perform data analysis, and generate reports. Other computer-based tools enable teachers to quickly generate individualized communications to parents, create lesson plans, and select instructional materials from a rich resource database. If entire schools or districts use such capabilities, record keeping and communication can be dramatically enhanced. (Peck \& Dorricott, 1994, p. 14)

This optimistic hype reminds me of the story when electricity first lit up the shop windows in New York, in 1886. The effect on the public was amazing. "So powerful was the new medium that scientists and engineers of the day predicted that its widespread use would make cities green, heal the breach between the classes, create a wealth of new goods, extend day into night, cure age-old diseases, and bring peace and harmony to the world." (Rifkin 1995, p. 43) Awesome and interesting rhetoric, but not many of those predictions have been realized. We do live in interesting times and there are a variety of views of heaven and hell!

A careful reading of the literature suggests to me that four major factors will impact upon us as we continue our path of living and learning in the global village. These I have chosen to characterize as the four C's: collaborative critical literacy, connectivity, creating a civil society, and critical multiculturalism. Together these can form the foundation of a new educational age which fosters equity, growth and social justice for all. These also represent an optimistic view of a desirable future for education. Each has serious implications for children, for schools and for teacher-librarians and indeed, for our survival as a democratic society.

\section{COLLABORATIVE CRITICAL LITERACY}

Jim Cummins and Denis Sayers in their book Brave new schools: Challenging cultural illiteracy through global learning networks (1995), describe three different types of literacies. Functional literacy "implies a level of reading and writing that enables people to function adequately in social and employment situations typical of late twentieth century industrialized countries." (1995, p. 88) Functional literacy is what the Organization for Economic Cooperation and Development (OECD), the Conference Board of Canada, the chambers of commerce in most communities, and neo-conservatives in all jurisdictions, support as the raison d'etre of schools. In other words, give our kids enough basic skills to survive in the workplace so that they can become productive citizens, consumers, taxpayers and voters in order to support the status quo. You will find pronouncements of the importance of functional literacy embedded within the aims and goals of most ministries, or departments of education throughout the world.

There is a wonderful story that was first told in Aldous Huxley's, Brave New World that illustrates what functional literacy is:

A small boy asleep on his right side, the right arm stuck out, the right hand hanging over the edge of the bed. Through a round grating in the side of a box a voice speaks softly. "The Nile is the longest river in Africa and the second in length of all rivers of the globe. Although falling short of the length of the MississippiMissouri, the Nile is at the head of all rivers as regards the length of its basin, which extends through 35 degrees of latitude..."

At breakfast the next morning, "Tommy," someone says, "do you know which is the longest river in Africa?" A shaking of the head. "But don't you remember something that begins: The Nile is the...

"The Nile is the longest river in Africa and the second in length of all the rivers of the globe..." The words come rushing out. "Although falling short of..." 


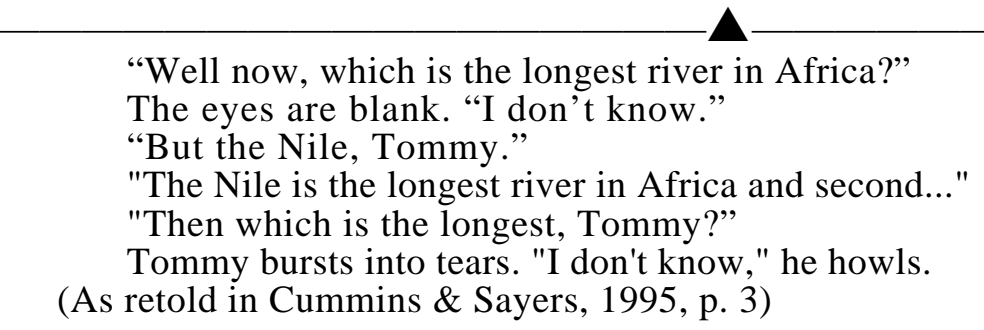

The focus on functional literacy is predicated on the notion of the child as an empty vessel into which the teacher pours information. Some know this model as the banking model of education or literacy that only reads the word as opposed to the world (Freire, 1974). We should all be familiar with this model as it is the way most of us experienced schooling. We learned by listening to teachers and reading textbooks. Our curriculum emphasized mastery of skills and concepts organized around discrete subject areas. Most of us were tracked into different learning groups. We were tested on our ability to recall information, rather than on our ability to understand or apply that information in a meaningful way.

Cultural literacy, the second form of literacy "emphasizes the need for shared experiences, knowledge, and expectations in order to comprehend adequately texts, media or patterns of social interaction within particular communities." (Cummins \& Sayers, 1995, p. 88) Cultural literacy helps to explain why cricket is so important in certain countries, while baseball thrives in others(why the Superbowl creates so much hype in the United States and the World Cup soccer matches elicit a yawn. Several educational reformers including Mortimer Adler (1982) and E. D. Hirsch (1987) have developed very sophisticated lists of subjects and content that all educated persons should know. A number of American states have latched onto these as frameworks for curriculum reform. The problem with cultural literacy is whose culture is to be legitimized and at whose expense? Hirsch's model, for example, focuses primarily on literary contributions from the United States and Western Europe and marginalizes anything worthwhile from Asia, Africa and Australia. Some critics argue that this approach in fact, supports the notion of monoculturalism. This type of cultural literacy formed the foundation for movements such as communism, Nazism and fascism.

Critical literacy, the deepest form of literacy is defined as "habits of thought, reading, writing and speaking which go beneath surface meaning, first impressions, dominant myths, official pronouncements, traditional clichés, received wisdom and mere opinions, to understand the deep meaning, root causes, social context, ideology, and personal consequences of any action, event, object, process, organization, experience, text, subject matter, policy, mass media, or discourse." (Shor, 1992, p. 129) Critical literacy implies life long learning. It means challenging the status quo and fosters not only developing students' critical awareness and understanding, but also critical autonomy. Critical literacy is what teacher-librarians have been advocating and trying to teach for many years. The teaching of critical information literacy is found within sources such as the Big Six (Skills approach, Information Power and other national provincial and local associations' role descriptions for teacherlibrarians (Eisenberg \& Berkowitz, 1990; American Association of School Librarians and Association for Educational Communications \& Technology, 1988).

The focus on collaboration and critical literacy is further reinforced in a very important work by Robert Reich (1991). In The work of nations: Preparing ourselves for 21st century capitalism, Reich develops the notion of the importance of what he calls symbolic analysis skills for an economy shifting from high volume to high value production. These skills include:

- Reich develops the notion of the importance of what he calls symbolic analysis skills for an economy shifting from high volume to high value production. These skills include:

- Abstraction(the capacity to order and make meaning of the massive flow of information,

to shape raw data into workable patterns;

- System thinking(the capacity to see the parts in relation to the whole, to see why

problems arise;

- Experimental inquiry(the capacity to set up procedures to test and evaluate alternate ideas; 
- Collaboration(the capacity to engage in active communication and dialogue to get a variety of perspectives and to create consensus when that is necessary.

Having kids working on projects, defining an issue, carrying out research, interpreting the data and then collaborating in searching for solutions to the problems identified constitutes symbolic analysis. That is strange. I thought that was called the Big Six ( Skills Approach. Regardless of what we call it, these kids are developing skills that will help them be competitive in the global economy where a highly skilled workforce is required. The focus on critical inquiry of local and global issues might lead students to become more socially active in their own communities and foster a more authentic relationship between the curriculum and the real life world.

T'hus far we have talked about critical literacy. The notion of collaborative critical literacy builds further upon the concept of cooperative program planning and teaching again, something teacher-librarians have been doing for more than 20 years. The collaborative critical literacy model, however, extends beyond cooperative program planning and teaching, and attempts to be transformative by bringing about substantive change by focusing on preparing students for democratic education and the pursuit of social justice. Eight components are incorporated in classrooms oriented toward critical literacy in the social justice classroom. These include having curriculum and classroom practice:

Eight components are incorporated in classrooms oriented toward critical literacy in the social justice classroom. These include having curriculum and classroom practice:

- Grounded in the lives of students. All good teaching begins with respect for children, their innate curiosity and their capacity to learn. Students should probe the ways their lives connect to the broader society and are often limited by that society. All good teaching begins with respect for children, their innate curiosity and their capacity to learn. Students should probe the ways their lives connect to the broader society and are often limited by that society.

- Critical. Students must learn to pose essential critical questions. Who makes decisions and who is left out? Who benefits and who suffers ? What alternatives can we imagine? Finally, student work must move outside the classroom walls, so that scholastic learning is linked to real world problems.

- Multicultural, antiracist and pro-justice. Curriculum must strive to include the lives of those in our society, especially the marginalized and dominated and engage children in a critique of the roots of inequality in curriculum, school structure, and the larger society.

- Participatory and experiential. Our classrooms also must provoke students to develop their democratic capacities: to question, to challenge, to make real decisions, to collectively solve problems. Our classrooms also must provoke students to develop their democratic capacities: to question, to challenge, to make real decisions, to collectively solve problems.

- Hopeful, joyful, kind and visionary. We need to design activities where students learn to trust and care for each other. Together students and teachers can create a community of conscience. We need to design activities where students learn to trust and care for each other. Together students and teachers can create a community of conscience.

- Activist. We want students to see themselves a truth-tellers and change- makers.

- Academically rigorous. A social justice classroom equips children not only to change the world but also to maneuver in the one that exists. Critical teaching aims to inspire levels of academic performance far greater than those motivated by grades and test scores. A social justice classroom equips children not only to change the world but also to maneuver in the one that exists. Critical teaching aims to inspire levels of academic performance far greater than those motivated by grades and test scores. 
- Culturally sensitive. When teachers are teaching children who are different from themselves they must call upon p parents in a collaborative fashion if they are to learn who their students really are. (Bigelow, Christensen, Karp, Miner, \& Peterson, 1994, pp. 4-5)

The power of the Internet to allow children to engage in collaborative literacy inquiry with each other, within their schools within their district, province or state, within their country or with other countries is evident.

\section{CONNECTIVITY}

The second major theme I would like to address is that of connectivity. Here we are referring not only to the physical and technological but also the social connection within schools and between schools and school districts and the communities which they serve. Our schools continue to operate as extensions of the one room red schoolhouse where teachers are isolated from one another by architecture, timetables and overload (Fullan, 1988; Fullan \& Hargreaves, 1991). This isolation has led to increased teacher individualism (part of the reason why teacher librarians have had difficulty in working collaboratively with some teachers) which mitigates against collegiality and cooperative school improvement activities. There is a significant body of research that describes improving schools where teachers worked together more in a collaborative and collegial manner. "It is assumed that improvement in teaching is a collective rather than individual enterprise, and that analysis, evaluation and experimentation in concert with colleagues are conditions under which teachers improve." (Fullan \& Hargreaves, 1991, p. 44) Schools of the twenty-first century can only survive if teachers pull together collectively in what Glickman calls a cause beyond oneself where "teachers see themselves as part of the larger enterprise of complementing and working with each other to educate students." (Glickman, 1990, p. 20)

Our schools also are not well connected to the communities which they serve. Schools in the future will have to develop purposeful, productive and authentic relationships with their communities. "Business leaders and school leaders must come to understand that the emergence of the information-based economy is creating a condition where the need for alliances between business and education is even more compelling." (Schlechty, 1990, p. 15) Students learn about the community by direct participation and involvement with it. The relationships between the school home and community must be seamless, understood and internalized, Schools can only be successful when the community supports its efforts. "We must understand the interdependence of the quality of life in our community and the quality of life of our schools." (Negroni 1996, p. 218)

We must be careful how we exploit these relationships with our business communities and pay heed to the concerns raised by Maude Barlow and Heather-Jane Robertson in Class Warfare (1994). These authors caution schools to be wary of the business agenda whose intent is to build ideological alliances for the corporate agenda, business' wishing to gain access to new markets (schools now represent one of the largest untapped market shares for business), and business's focus on raising the future workforce. As we reach out and establish new working relationships with the community, we must try to recapture that spirit which created the notion that it takes a whole village to educate a child.

"They used to say that school could teach somebody 80 percent of what they need to learn in their lifetime. Today that figure would probably be more like two percent. Schools need to focus on thinking skills and learning skills because those are what will prepare kids for a world of increasing independency and increasing change." (O'Neil, 1995, pp. 22-23) Developing those skills in an authentic community environment reinforces the notion of a village-based support system for the education of all children.

\section{CREATING A CIVIL SOCIETY}

One of the most interesting works to be published in the last few years is a book by Jeremy Rifkin (1995), entitled The end of work: The decline of the global labour force and the dawn of the post-market era. In this work and others like it, strong arguments are raised about the end of the job as we have come to know it. argues that information age technologies are replacing human beings in 
every industry. He predicts that over the next quarter century we will see the virtual elimination of blue collar, mass assembly-line workers from the production process. In the 1800's more than 80 percent of our nation's workforce was engaged in agriculture; in 1996, only 1.9 percent remained. Futurists are predicting that by the year 2020 less than 2 percent of the global workforce will be engaged in manufacturing (Rifkin, 1995). We are already seeing the impact. In 1973, 16 percent of the population in the 18-24 year old range lived at home because they could not afford to support themselves independently; in 1994, that number had risen to 41 percent. Not only are we losing jobs, but the jobs that are being created in the service sector are the low paying ones. Almost one third of all workers hold temporary or part-time jobs. If present trends continue, by the year 2000, half of Canadians win be contingency workers (Barlow \& Robertson, 1994, p. 70). The myth that big business is creating highly skilled jobs is not backed up anywhere (p. 69). Rifkin (1997) suggests that since jobs in the first sector-the marketplace-are being eliminated and the government-the second sector-is downsizing, the third sector-the non profit sector or non governmental organizations - may be the best hope for creating new kinds of employment. His suggestions have major implications for the very purpose of education. Instead of preparing children for the marketplace and sustaining the status quo, Rifkin supports the notion of investing in a renewed commitment to the improvement of the country. This renewal creates what Rifkin calls social capital, which is based on the notion of freely giving of one's time, energy, talent and skills to help others and advance the interests of the community. By doing so each individual's own interests are optimized. Preparing students to live in a civil society would involve major curriculum changes which would focus on democracy in action. Such a curriculum might include extensions of cooperative work experiences and credit assigned for voluntary contributions.

At a time when teachers, parents and communities are concerned about the growing alienation, detachment, and aimlessness of students civil education engenders a sense of personal responsibility and accountability, fosters self esteem and leadership, and most of all, allows empathy to grow. (p. 33)

If we are concerned about declining levels of voter participation and public apathy, and kids opting out of society generally, what Rifkin proposes makes a lot of sense. The future of our society will depend on the values and decisions that these people will make in the future. Civil education can restore the notion that it takes a whole village to educate a child.

\section{CRITICAL MULTICULTURALISM}

Thus far we have talked about collaborative critical literacy, connectivity, and creating a civil society let us now turn to the fourth factor which impacts on living and learning in the global village. The defining attribute of the information age is to shrink the world so that for the first time in history we can speak of a global community. "Perhaps the major challenge for us individuals and a global society is learning how to work together across cultural and linguistic differences in ways that generate empowerment for all participants." (Cummins \& Sayers, 1995, p. 166)

Governments in the last 20 years have paid increased attention to the notion of multicultural and antiracist education. Several regulations, policies and resource documents have been produced for school use (Ontario Ministry of Education, 1992; Ontario Ministry of Education and Training, 1993). Many of these support including, in both the school environment and curriculum practices and content that reflect the diverse cultural backgrounds represented in a pluralistic society. Others support diversity and promoting awareness and understanding of the various cultural groups and recognizing their intrinsic value and significance. All such documents purport to attempt to correct distortions and remedy emissions and discriminatory conditions and to establish practices and procedures consistent with the goals of equity education.

Just as we described several levels of literacy, we have seen an evolution of multicultural approaches that have moved from the contributions approach, focusing on teaching about customs and holidays, to the additive approach where concepts, themes, and perspectives are added as units of study to the curriculum. An example of this might be a celebration of Black history week. The third approach is the transformative approach, in which the curriculum is changed to view issues and concepts from diverse perspectives. Here, instead of studying just Western civilization we might also 
look at India, Africa or Japan. We also begin to ask different kinds of questions such as: Whose interest is it that we study what we study? Why is it that certain kinds of knowledge get hidden? (Bigelow, et al. 1994, pp. 19-22) The social action approach is one in which the curriculum and instruction help lead to change outside of schools and students are empowered to bringing upon changes where injustices exist through social action.

Most observers agree that our efforts in multicultural education over the last twenty years have not been successful in providing solutions to the problem of racial inequality in schools, and in fact "the programs and policies, despite their cost, have simply added a new veneer to the outward facade of the structure that continues to disable minority students." (Cummins, 1986, pp. 50-68) Research (McCarthy, 1995) tells us that minority girls and boys are more likely than their white peers to be placed in low or nonacademic tracks, that teachers' encouragement and expectations of academic performance are considerably lower for black and Hispanic students than for white students, that black students have access to fewer instructional opportunities than white students and that ultimately black, Hispanic and Native American youth are more likely to drop out of schools than white youth.

The critical multicultural approach attempts to go beyond traditional approaches to multiculturalism by examining critically how school knowledge is constructed and challenging the privileging of Eurocentric and western perspectives in our curriculum. Critical multiculturalism seeks to promote democratic initiatives in curriculum and pedagogic practices and social relations in schools to increase minority success rates in schools. The curriculum brings the uninstitutionalized experiences of marginalized minorities and working class women and men to the center of the school curriculum. "The notion here is that if you wish to teach about ethnicity and race relations a more comprehensive and deeper understanding is possible if you construct your curriculum from the point of view of the subordinated ethnic groups than if you work from the point of the dominant one." (McCarthy, 1995 p. 42)

If we invest in the diverse, cultural linguistic and intellectual capital that all students bring to school we can create a highly skilled workforce amply endowed with the capacities for symbolic analysis. This workforce will have far greater ability to create wealth through innovation and manipulation of information than is now the case. As a consequence, it will have greater financial assets, which will spur consumption and further production. Far fewer expenditures will be required on welfare, surveillance and incarceration, saving our societies billions of dollars annually. (Cummins \& Sayers, 1995, pp. 170-171)

\section{CONCLUSION}

Living and learning in the global village presents us with the opportunity to transform our schools and our society. In this paper I have tried to identify four trends which I see as guidelines for this transformation. I have argued that collaborative critical inquiry changes the nature of knowing from regurgitating and recalling information to defining and posing problems, locating, retrieving, using and communicating information and is essential in the information age. I have suggested that schools and teachers must establish authentic connections with the communities that they serve and form partnerships that together can establish classrooms as places of hope where students, teachers and parents can gain glimpses of a society that is just for all. As the whole nature of work changes and as we move from a market economy, driven by consumption and profit, to one that attends to societal benefit we can indeed create a civil society one based on true social justice. The problems of our schools and in our society will not be resolved until we resolve ways of working together across gender, class and race. It is only when we restructure our curricular our pedagogical approaches and our own attitudes that true equity will be achieved. 


\section{REFERENCES}

Abbott, J. (1995). Children need communities. Educational Leadership, 52(8), 6- 10.

Adler, M. (1982). The Paideia Proposal: An educational manifesto. New York: Macmillan.

American Association of School Librarians and Association for Educational Communications and Technology. (1988). Information power: Guidelines for school library media programs. Chicago: American Library Association.

Barlow, M., \& Robertson, H. J. (1994). Class Warfare: The assault on Canada's schools. Toronto: Key Porter

Betts, F. (1994). On the birth of the communication age: A conversation with David Thornburg. Educational Leadership, 51(7), 20-23.

Bigelow, B., Christensen, L., Karp, S., Miner., \& Peterson, B. (1994). Rethinking our classrooms: Teaching for equity and justice. Milwaukee, WI: Rethinking Schools.

Cummins, J. (1986). Empowering minority students: A framework for intervention. Harvard Educational Review, 56(1), 50-68.

Cummins, J. \& Sayers, D. (1995). Brave New Schools: Challenging cultural illiteracy through global learning networks. New York: St. Martin's.

Dryden, K. (1995). In school: Our kids, our teachers, our classrooms. Toronto: McClelland \& Stewart.

Dwyer, D. (1994). Apple classrooms of tomorrow: What we've learned. Educational Leadership, 5 (7), 4-10

Eisenberg, M., \& Berkowitz, R- (1990). Information problem solving: The big six approach to library and information skills instruction. Norwood, NJ: Ablex Publishing Corp.

Freire, P. (1970). Pedagogy of the oppressed. New York: Herder \& Herder.

Fullan, M. (1988). What's worth fighting for in the principalship? Strategies for taking charge in the elementary school principalship. Toronto: Ontario Public School Teachers' Federation.

Fullan, M., \& Hargreaves, A. (1991). What's Worth Fighting For? Working together for your school. Toronto: Ontario Public School Teachers' Federation.

Glickman, C. (1990). Supervision of Instruction: A developmental approach. (2nd ed.) Boston: Allyn \& Bacon.

Hancock, V., \& Betts, F. (1994). From the lagging to the leading edge. Educational Leadership, 51(7), 24-29

Hide, A., \& Soilborne, L. (I 996). The teacher's complete \& easy guide to the Internet. Toronto: Trifolium.

Hirsch, E., Jr. (1987) Cultural literacy: What every American needs to know. Boston: Houghton

McCarthy, C. (1995). Multicultural policy discourses on racial inequality in American education. In R. Ng, P. Staton \& J. Scane (Eds.), Anit-racism feminism and critical approaches to education. (pp. 21-43). Westport, CT: Bergin \& Garvey.

Negroni, P. (1996). The transformation of Public Schools. In C. E. Walsh (Ed.), Education reform and social change: Multicultural voices, struggles and visions. Mahwah, NJ: Lawrence Erlbaum.

November, A. (1995). The end of the job. Speech presented to the 1995 Educational Computing Organization of Ontario, Annual Conference. May 1996,

O'Neil, J. (1995). On schools as learning organizations: A conversation with Peter Senge. Educational Leadership, 52(7), 20-23.

Ontario Ministry of Education. (I 992). Changing perspectives: A resource guide for antiracist and ethnocultural-equity education. Toronto: Queen's Printer.

Ontario Ministry of Education and Training. (1993). Antiracism and ethnocultural equity in school boards: Guidelines for policy development and implementation. Toronto: Queen's Printer.

Peck, K, \& Dorricott, D. (1994). Why use technology? Educational Leadership, 5 (7), 11-14.

Rhodes, L. (1996). Looking through a different lens: A new view of information technology. Learning and Leading with Technology, 23(6), 42-59.

Rhodes, L. (I 996). Seeking new connections: learning, technology, and systemic change. Learning and Leading with Technology, 23(8), 45-56.

Rifkin, J. (1995). The end of work: The decline of the global labor force and the dawn of the postmarket era. New York: G. P. Putnam's Sons. 
Rifkin, J. (1997). Preparing students for "the end of work." Educational Leadership, 54(5), 30-33. Schlechty, P. (1990). Schools for the twenty-first century: leadership imperatives for educational reform. San Francisco: Jossey Bass.

Shor, I. (1992). Empowering education: Critical teaching for social change. Chicago: University of Chicago Press.

Stearn, G.E., Ed. (1967). McLuhan: Hot and cool. Toronto: New American Library.

Wadsworth, D. (1997). The public's view of public schools. Educational Leadership, 54(5), 44-47. 